\title{
BODY IMAGE SISWA-SISWI YANG MENGALAMI OBESITAS DI SMA NEGERI 8 DENPASAR
}

\author{
Windu Astutik ${ }^{1}$, GA. Ratih Kusuma Wardani² \\ ${ }^{1,2}$ STIKES Kesdam IX/Udayana \\ Alamat Korespondensi: wnd.ners@gmail.com
}

\begin{abstract}
Abstrak
Masa remaja merupakan suatu periode pada masa pertumbuhan dan proses kematangan manusia. Obesitas merupakan suatu kondisi dimana terjadinya penumpukan lemak tubuh yang berlebih, sehingga berat badan seseorang jauh diatas batas normal. Prevalensi obesitas di Kota Denpasar sebesar 10,5\% atau sebanyak 11.730 orang dengan jumlah laki-laki 5.371 orang dan perempuan 6.359 orang. Body image merupakan kumpulan dari sikap-sikap individu terhadap tubuhnya termasuk persepsi masa lalu dan sekarang, serta perasaan tentang stuktur, bentuk, dan fungsi tubuh. Penelitian ini bertujuan untuk mengetahui gambaran body image siswa-siswi yang mengalami obesitas di SMA N 8 Denpasar. Populasi dalam penelitian ini siswa-siswi yang mengalami obesitas dan pengambilan subjek penelitian menggunakan teknik sampling total sampling sebanyak 63 orang. Instrumen yang digunakan adalah kuesioner Multidimensional Body Self Relations Questionnaire (MBSRQ). Hasil penelitian ini didapatkan bahwa responden obesitas yang mengalami citra tubuh positif sebanyak 59 orang $(93,6 \%)$ dan yang mengalami citra tubuh negatif sebanyak empat orang $(6,4 \%)$. Dapat disimpulkan bahwa sebagian besar responden di SMA N 8 Denpasar memiliki citra tubuh yang positif.
\end{abstract}

Kata kunci: Body image, Obesitas, Remaja.

\begin{abstract}
Adolescence is a period in a period of growth and processes of maturity man. Obesity is a condition in which the amass excess body fat, so weight someone is way up to normal limits. Prevalence of obesity in the city Denpasar of $10,5 \%$ or as many as 11.730 people with of men 5.371 people and women 6.359 one. Body image is a collection of an individual to his body of perception past and present, road structure and feeling about, form, and bodily functions. The research aims to understand a body image in obesity in the state SMAN 8 Denpasar. Population in this study in obesity and take the subject of study uses the technique of sampling total of sampling as many as 63 one. The instrument used is the body of this multi-dimensional selfrelations questionnaire (MBSRQ). The result of this research got that respondents obesity that experienced the body image positif as many as 59 people $(93.6 \%)$ and suffered from the body image negatif as much as four people $(6.4 \%)$. It can be concluded that the majority of respondents in SMAN 8 Denpasar having a positif body image.
\end{abstract}

Keywords: Body Image, Obesity, Teenager. 


\section{PENDAHULUAN}

Masa remaja merupakan suatu periode pada masa pertumbuhan dan proses kematangan manusia, pada masa ini terjadi perubahan yang sangat unik dan berkelanjutan (Santrock, 2010). Jumlah penduduk remaja di Indonesia menurut Badan Pusat Statistik (2019) sebanyak 66,1 juta, jika dibandingkan dengan usia lainnya penduduk kanak-kanak sebanyak 43,8 juta, penduduk dewasa sebanyak 83,1 juta, sedangkan penduduk lansia sebanyak 72,4 juta. Jumlah penduduk remaja di Bali menurut Badan Pusat Statistik Provinsi Bali (2020) sebanyak 1.019 ribu, jika dibandingkan dengan usia lainnya penduduk kanak-kanak sebanyak 651 ribu, penduduk dewasa sebanyak 1.335 ribu, sedangkan penduduk lansia sebanyak 1.376 ribu.

Perkembangan pada masa remaja dibagi menjadi 3 tahap, yaitu: tahap remaja awal yaitu usia 10-14 tahun dimana remaja mengalami pertumbuhan fisik dan seksual dengan sangat cepat, tahap remaja pertengahan yaitu usia 15-17 tahun dimana remaja mengalami masa susah, tahap remaja akhir yaitu usia 18-21 tahun dimana remaja mengalami pemikiran operasional formal penuh mengenai masa depan (Santrock, 2010). Perubahan besar yang terjadi adalah peningkatan berat dan tinggi badan, pubertas, lebih banyak berinteraksi remaja dengan teman sebaya, berpikir krisis, dan puncak emosi yang labil (Herlina, 2013; Sarwono, 2011). Peningkatan mengkonsumsi makanan yang cepat saji dan rendahnya aktivitas fisik dapat menyebabkan peningkatan berat badan hingga obesitas (Kurdanti, 2015).

Obesitas merupakan suatu kondisi dimana terjadinya penumpukan lemak tubuh yang berlebih, sehingga berat badan seseorang jauh diatas batas normal. World Health Organization (WHO) melaporkan bahwa pada tahun 2015 sekitar 2,3 miliyar remaja usia 15 tahun ke atas mengalami kelebihan berat badan, dari jumlah tersebut lebih dari 700 juta mengalami obesitas, dengan prevalensi sebesar $11 \%$ pada lakilaki, dan $12 \%$ pada perempuan. Kejadian obesitas di Indonesia memiliki prevalensi obesitas pada remaja $\geq 15$ tahun sebesar $31,0 \%$. Kota Denpasar mencatat prevalensi obesitas sebesar 10,5\% atau sebanyak 11.730 orang dengan jumlah laki-laki 5.371 orang dan perempuan 6.359 orang (Riskesdas, 2018).

Obesitas pada remaja berdampak pada fisik dan psikologisnya. Risiko penyakit yang akan timbul karena obesitas yaitu diabetes mellitus tipe 2, iskemik stroke dan jantung koroner dapat terjadi dengan meningkatnya Indeks Massa Tubuh (IMT). Dampak psikologis pada remaja obesitas adalah timbulnya rasa malu dan rasa kurang percaya diri. Hal tersebut dapat menyebabkan perubahan konsep diri. Body image merupakan kumpulan dari sikap-sikap individu terhadap tubuhnya termasuk persepsi masa lalu dan sekarang, serta perasaan tentang stuktur, bentuk, dan fungsi tubuh (Keliat, 2011). Sebanyak 93,5\% remaja putri obesitas memiliki body image negatif (Wati dan Sumarmi, 2017). Remaja obesitas memiliki rasa ketidakpuasan akan body imagenya dan berharap memiliki tubuh yang lebih kecil. Penelitian ini bertujuan untuk mengetahui gambaran body image siswa-siswi SMA Negeri 8 Denpasar yang mengalami obesitas melalui penelitian kuantitatif.

\section{METODE PENELITIAN}

Penelitian ini merupakan penelitian kuantitatif dengan pendekatan deskriptif analitik. Populasi penelitian ini adalah siswasiswi di SMA Negeri 8 Denpasar dengan jumlah sampel 63 orang. Alat pengumpul data dalam penelitian ini menggunakan kuesioner Multidimensional Body Self Relations Questionnaire (MBSRQ) yang dikembangkan oleh Cash (2000) yang sudah di gunakan dalam penelitian sebelumnya 
yang berisikan 38 pernyataan. Uji validasi yang dilakukan penelitian Rosiana didapatkan nilai $\mathrm{p}=0.039$. Data hasil penelitian dianalisis secara univariat menggunakan distribusi frekuensi.

Tabel 1. Karakteristik responden $(n=63)$

\begin{tabular}{|c|c|c|c|c|c|c|}
\hline \multirow{3}{*}{$\begin{array}{c}\text { Karakteristik } \\
\text { Responden }\end{array}$} & \multicolumn{4}{|c|}{ Obesitas } & \multicolumn{2}{|c|}{ Total } \\
\hline & \multicolumn{2}{|c|}{$\mathbf{I}$} & \multicolumn{2}{|c|}{ II } & \multirow[b]{2}{*}{$\begin{array}{c}\text { Frekuensi } \\
\text { (f) }\end{array}$} & \multirow[b]{2}{*}{$\begin{array}{c}\text { Presentase } \\
(\%)\end{array}$} \\
\hline & Frekuensi (f) & $\begin{array}{c}\text { Persentase } \\
(\%)\end{array}$ & $\begin{array}{l}\text { Frekuensi } \\
\text { (f) }\end{array}$ & $\begin{array}{c}\text { Persentase } \\
(\%)\end{array}$ & & \\
\hline \multicolumn{7}{|l|}{ Usia } \\
\hline $16-17$ tahun & 56 & 88,9 & 6 & 9,5 & 62 & 98,4 \\
\hline$\geq 18$ tahun & 1 & 1,6 & 0 & 0 & 1 & 1,6 \\
\hline \multicolumn{7}{|l|}{ Jenis Kelamin } \\
\hline Perempuan & 35 & 55,5 & 4 & 6,3 & 39 & 61,8 \\
\hline Laki-laki & 22 & 35 & 2 & 3,2 & 24 & 38,2 \\
\hline
\end{tabular}

Hasil penelitian menunjukkan mayoritas responden mengalami obesitas tipe I (90,
$5 \%)$, berusia $16-17$ tahun $(62 \%)$ dan berjenis kelamin perempuan $(61,8 \%)$.

Tabel 2. Body image Siswa-Siswi SMA Negeri 8 Denpasar Yang Mengalami Obesitas (n=63)

\begin{tabular}{cccccccc}
\hline & \multicolumn{4}{c}{ Body image } & \multicolumn{2}{c}{ Total } \\
\cline { 2 - 7 } Obesitas & \multicolumn{2}{c}{ Positif } & \multicolumn{3}{c}{ Negatif (gangguan) } & \multicolumn{2}{c}{} \\
\cline { 2 - 7 } & \multirow{2}{*}{ Frekuensi (f) } & $\begin{array}{c}\text { Persentase } \\
(\boldsymbol{\%})\end{array}$ & $\begin{array}{c}\text { Frekuensi } \\
\text { (f) }\end{array}$ & $\begin{array}{c}\text { Persentase } \\
(\boldsymbol{\%})\end{array}$ & $\begin{array}{c}\text { Frekuensi } \\
(\mathbf{f})\end{array}$ & $\begin{array}{c}\text { Presentase } \\
(\boldsymbol{\%})\end{array}$ \\
\hline Obesitas I & 53 & 84,1 & 4 & 6,4 & 57 & 18,7 \\
Obesitas II & 6 & 9,5 & 0 & 0 & 6 & 2 \\
\hline
\end{tabular}

Hasil penelitian menunjukkan bahwa sebagian besar responden yang mengalami obesitas memiliki body image yang positif (93.6\%). Obesitas tipe I memiliki body image negatif lebih banyak dibandingkan obesitas tipe II.

\section{PEMBAHASAN}

Hasil penelitian menunjukkan bahwa sebagian besar responden yang mengalami obesitas I dan II berusia 17 tahun. Remaja merupakan suatu tahap perkembangan yang unik dimana terjadi perubahan dalam pertumbuhan dan perkembangan (Stuart, 2013). Pada masa perkembangan, remaja mengalami perubahan-perubahan secara kompleks yang meliputi perubahan fisik/biologis, psikoseksual, kognitif, sosial dan emosi. Perubahan besar yang terjadi adalah peningkatan berat badan dan tinggi badan, pubertas, lebih banyak berinteraksi remaja dengan teman sebaya, berpikir kritis, dan puncak emosi labil (Herlina, 2013; Sarwono, 2011). Didukung oleh penelitian Rahmawati (2013) mengatakan bahwa perhatian terhadap berat badan seseorang sangat kuat terjadi pada remaja yang berusia 12-18 tahun, baik remaja putri ataupun remaja putra. Menurut Riskesdas (2013) yang menyatakan bahwa pada remaja usia 16-18 tahun sebanyak $7,3 \%$ yang terdiri dari $5,7 \%$ gemuk dan $1,6 \%$ obesitas.

Hasil penelitian menunjukkan bahwa sebagian besar responden yang mengalami obesitas I dan II berjenis kelamin perempuan. Sesuai dengan penelitian Rahmawati (2013) yang menyatakan bahwa bagi remaja putri yang mengalami obesitas, masalah yang sering kali terjadi adalah gangguan body image dan kondisi ini berbeda dengan remaja putra yang lebih mengutamakan prestasi daripada mengurus bentuk tubuh yang ideal. 
Perempuan merasa tidak puas dengan bentuk tubuhnya dan berusaha untuk menurunkan berat badannya meskipun sudah memiliki tubuh yang ideal. Bertambahnya berat badan akan menjadi permasalahan yang cukup berat bagi remaja remaja putri karena tampil sempurna dapat disalahartikan dengan memiliki tubuh yang begitu proporsional (Suandi, 2010).

Menurut Souegih dan Wiramihardja (2010) obesitas pada perempuan dapat disebabkan oleh pengaruh hormon estrogen. Salah satu fungsi hormon estrogen adalah untuk mengembangkan dan mempertahankan tanda-tanda fisik perempuan. Perbandingan jumlah lemak yang dimiliki oleh perempuan sekitar 25$30 \%$ dan laki-laki 18-23\%. Menurut Ekawati (2014) bahwa salah satu penyebab obesitas pada perempuan yaitu dapat disebabkan oleh pengaruh hormon estrogen. Perempuan lebih banyak memiliki hormon estrogen dibandingkan dengan laki-laki. Hal ini dapat menyebabkan perempuan lebih cepat mengalami obesitas. Rata-rata perempuan memiliki cadangan lemak tubuh yang lebih banyak dibandingkan dengan laki-laki.

Body image adalah sikap seseorang terhadap tubuhnya. Sikap ini mencakup persepsi dan perasaan tentang ukuran, bentuk, fungsi, dan potensi tubuh saat ini dan masa lalu yang secara berkesinambungan dapat dimodifikasi dengan pengalaman baru setiap individu (Muhith, 2015). Dari penelitian yang telah dilakukan pada 63 orang siswa-siswi SMA Negeri 8 Denpasar yang mengalami obesitas, hasil yang didapatkan pada penelitian ini menunjukkan bahwa 59 responden obesitas yang mengalami body image positif dan 4 responden obesitas yang mengalami body image negatif atau mengalami gangguan. Responden dengan body image positif memiliki gambaran tentang tubuhnya secara positif, biasanya ditandai dengan perasaan puas menerima tubuhnya selain itu tidak mengkhawatirkan makanan yang ingin dimakan. Oleh karena itu, body image positif kebanyakan responden tidak mengatur pola makannya sehingga menyebabkan terjadinya obesitas (Vindi, 2018). Hal ini di perkuat oleh penelitian Iswari dan Wilani (2013) bahwa konsep diri yang positif akan membentuk penerimaan diri yang positif. Selain itu, adanya penerimaan sosial atau pengakuan dari orang lain akan mempengaruhi persepsi seseorang terhadap tubuhnya sehingga akan menimbulkan evaluasi terhadap penampilan, terutama pada remaja (Ammar \& Nurmala, 2020).

Beberapa hasil penelitian menunjukkan hal yang berbeda. Remaja putri overweight cenderung memiliki citra tubuh yang negatif, sedangkan remaja putri non overweight cenderung memiliki citra tubuh yang positif (Wati dan Sumarmi, 2017). Demikian juga dengan penelitian Ekawati (2014) yang menunjukkan bahwa body image remaja obesitas pada kategori positif sebanyak 18 orang $(43,9 \%)$. Penelitian lain yang berbeda hasil adalah penelitian Kinanti (2010) menunjukkan bahwa body image remaja obesitas yang pada kategori positif sebanyak 33 orang (33\%). Hal ini dapat terjadi karena faktor konsep diri. Individu yang memiliki konsep diri dapat memberikan penilaian positif terhadap tubuhnya dan dapat menghadapi kejadian yang mungkin mengancam body imagenya. Ketidakpuasan terhadap citra tubuh dapat menyebabkan remaja merasa kurang percaya diri, bahkan kurang bahagia.

\section{KESIMPULAN DAN SARAN}

Siswa-siswi yang mengalami obesitas sebagian besar memiliki body image yang positif dan sedikit sekali siswa-siswi obesitas yang memiliki body image negatif. Hasil penelitian ini dapat digunakan sebagai data dasar dalam penelitian selanjutnya, sehingga peneliti berharap peneliti selanjutnya dapat melakukan penelitian menggali faktor-faktor 
protektif pada konsep diri dan penelitian dengan memberikan intervensi dalam memelihara body image tetap positif dan meningkatkan kemampuan penerimaan diri pada usia remaja.

\section{DAFTAR PUSTAKA}

Ammar, E. N; Nurmala, I. (2020). Analysis Of Socio-Cultural Faktors On Dimensions Of Body Image As Bulimia Nervosa Prevention In Adolescents. Journal of Health Science and Prevention Vol 4 No 1

Badan Pusat Statistik. 2019. Statistik Penduduk Indonesia Pada Tahun 2019. Diperoleh pada tanggal 12 Maret 2020 dari http://www.bps.go.id/

Badan Pusat Statistik Provinsi Bali. 2020. Statistik Penduduk Bali Pada Tahun 2020. Diperoleh pada tanggal 12 Maret $2020 \quad$ dari http://www.bps.go.id/

Ekawati, A. (2014). Hubungan Obesitas Dengan Citra Tubuh Pada Mahasiswa Program Studi Ilmu Keperawatan Di Stikes 'Aisyiyas Yogyakarta. Diperoleh pada tanggal 15 Juli 2020.

Herlina. (2013). Perkembangan Masa remaja (Usia 11/12-18 tahun). Mengenai Masalah Anak dan Remaja. Diperoleh pada tanggal 3 Maret 2020 dari http://doi.org/http://doi.org/10.1016/

Iswari, N. K. A. S; Wilani, N. M. A. Pengaruh citra tubuh terhadap penyesuaian diri pada remaja awal di SMPN 1 Denpasar. Jurnal Psikologi Udayana, [S.1.], p. 12-21
Keliat, B. A. (2011). Keperawatan Kesehatan Jiwa Komunitas. Jakarta: EGC.

Kinanti, N. (2010). Gambaran Citra Tubuh Pada Remaja yang Obesitas. Diperoleh pada tanggal 15 Juli 2020.

Kurdianti, W, et al. (2015). Faktor-faktor yang Mempengeruhi Kejadian Obesitas pada Remaja. Jurnal Gizi Klinik Indonesia.

Muhith, A. (2015). Pendidikan Keperawatan Jiwa: Teori dan Aplikasi. Yogyakarta: Andi.

Riskesdas. (2018). Hasil Utama Riskesdas Tahun 2018 Kementrian Kesehatan Badan Penelitian Pengembangan Kesehatan.

Santrock, W. (2010). Remaja Jilid I (Edisi 11). Jakarta: Erlangga.

Sarwono, S. (2011). Psikologi Remaja. Jakarta: PT. Raja Grafindo.

Soegih, R., dan Wiramihardja. (2010). Obesitas Permasalahan dan Terapi Praktis. Jakarta: Sagung Seto.

Stuart, G.W. (2013). Psyciatric Nursing. (Edisi 10). Jakarta: EGC

Vindi, L. (2018). Hubungan Obesitas Dengan Gangguan Citra Tubuh Pada Remaja Putri Di Pondok Pesantren Al Munawwir Krapyak Yogyakarta. Diperoleh pada tanggal 15 Juli 2020.

Wati dan Sumarmi. (2017). Body Image Among Overweight and Non overweight Adolescent Girls: A Cross Sectional Study. Amerta Nutr (2017) 398-405

WHO. (2015). Angka Kejadian Obesitas. Diperoleh pada tanggal 29 Mei 2020 dari http://www.who.int/. 